peratures from $4^{\circ}$ to $45^{\circ} \mathrm{C}$, and is able to survive in sea water. This seems the most probable environmental source for this case.

Laboratories should be altered to the possibility of $A$ hydrophila as a potential pathogenic organism. Treatment with aminoglycosides and vigorous pulmonary and cardiovascular support is required. Clinicians should be aware of the virulence of this rare organism.

1 Baddourr LM, Baselski VS. Pneumonia due to Aeromonas hydrophila complex: epidemiologic clinical and microbiologic features. South Med J 1988;81:461-3.

2 Reines HD, Cook FV. Pneumonia and bacteremia due to Aeromonas hydrophila. Chest 1981;80:264-7.

3 Scott EG, Russell CM, Noel KT, Sproul AE. Aeromonas hydrophila sepsis in a previously healthy man. JAMA 1978;239:1742.
4 Waterworth PM. Laboratory control. In: Garrod LP, Lambert HP, Grady FO, eds. Antibiotic and chemotherapy. 5th ed. Edinburgh: Churchill Livingstone, 1981: 464-504.

5 Ellison RT, Mostow SR. Pyogenic meningitis manifesting during therapy for Aeromonas hydrophila sepsis. Arch Intern Med 1984;144:2078-9.

6 Dahm LJ, Weinberg AG. Plesiomonas (Aeromonas) shigelloides septicemia and meningitis in a neonate. South Med J 1980;73:393-4.

7 Yadava R, Seeler RA, Kalelkar M, Royal JE. Fatal Aeromonas hydrophila sepsis and meningitis in a child with sickle cell anemia. Am J Dis Child 1979;133:753-4.

8 Master R, Weisman MH, Armbuster TG, Slivka J, Resnick $\mathrm{D}$, Goerger TG. Sepsis arthritis of the glenohumeral joint. Unique clinical and radiographic festures and a favourable outcome. Arthr Rheum 1977;20:1500-6.

9 Gaussorgner P, Bachmann P, Tigand S, Piperno D, Jaboulay JM, Salord F, et al. Abces pulmonaire a Aeromonas hydrophila: complication de noyade en eau douce. Ann Med Intern 1987;138:666-7.

10 Plotkin GR, Scinico MW. Nosocomial pneumonia due to $A$ hydrophila. Pathol Med 1986;89:40-2.

\title{
Little Old New York
}

Having long since acquired the trappings of a backwoodsman, I sometimes contemplate with pleasure 1938. That was the year in which, aged 28 and fresh from a general medical registrarship, I sailed to New York with a view to furthering my knowledge of chest medicine. By good fortune, I was introduced to two of the most distinguished members of our specialtynamely, Dr Eugene Opie, professor of pathology at New York Hospital, and Professor J Burns Amberson of Bellevue Hospital, perhaps the best known chest physician at that time.

Reporting to Dr Opie, I was soon immersed in controversies over natural and acquired immunity and resistance to tuberculosis in various animal species, a subject on which a dozen or so doctors were working in his department. I was set the task of tracing the fate of tubercle bacilli after their intravenous injection into rats. I will never forget the occasion when a laboratory assistant called $\mathrm{Mr}$ Lardy dumped a large toffee tin on my bench containing 20-30 albino rats each weighing about 150 grams. With his aid in anaesthetising and holding them down, I made a nick in the groin and injected a measured dose of bacilli into the saphenous (or was it the femoral?) vein. To this day I believe that the veins were smaller than the needles I was required to insert, but with practice I became proficient. These and other tins of rats were killed at intervals from half an hour to six months and the numbers of bacilli in their lungs and elsewhere were counted. With the aid of Dr Opie, an article eventually appeared in the Archives of Pathology.

Soon after my arrival I was shown some radiographs of the chest of macacus rhesus monkeys with massive tuberculous hilar lymph nodes. Having commented that the films were all overexposed, I was delegated to radiograph up to 20 of them twice a week. In time, I learnt the technique of extracting them from their cages without being nipped and then carrying them, one in each hand with their arms behind their backs, to the obsolescent $x$ ray machine. With the monkeys breathing at 50-60 times a minute in short bursts and the machine needing an exposure of at least half a second, good timing was essential. I think I convinced the pathologists who had infected the monkeys that my films were an improvement.

Three times a week I had the privilege of joining the small group accompanying $\mathrm{Dr}$ Amberson on his ward rounds. It was an unforgettable experience. Quite apart from the clinical aspect, there was the sight of a busy city hospital with beds down the centre of the wards and along the corridors and much coming and going. After a particularly noisy distribution of newspapers during one round, Dr Amberson pointed out that the paperman possessed a quality that Sir William Osler insisted all good physicians should possess-namely, imperturbability. It seemed to me to be a desirable quality in anyone wishing to survive the hubbub of Bellevue and one that Dr Amberson possessed in good measure.

Some years later, on my next visit to New York, I called on Dr Opie and said I felt a little guilty that he had made possible such a splendid year and I had given so little in return. He pointed out that he had always welcomed postgraduates who were properly recommended, that his assistants covered a wide range of seniority, and that he tried to ensure that each one was given a task appropriate to his ability.

Is it fair for a clinician to burst into a scientific department and stay for only a year? Dr Opie seemed to think that it was. Maybe I provided a useful pair of hands in his overall study of immunity in tuberculosis and at the same time used my research fellowship profitably. Whatever the answer may be, the experience I gained in scientific methods in what was then affectionately called Little Old New York profoundly influenced my approach to clinical medicine.-NEVILLE C OSWALD 